\title{
Predation pressure of introduced mosquitofish (Gambusia holbrooki Girard), on the native zooplankton community. A case-study from representative habitats in the lower Mondego river Valley (Portugal).
}

\author{
C. L. Mieiro' ${ }^{1}$ J. A. Cabral ${ }^{1,2} \&$ J. C. Marques'
}

${ }^{1}$ IMAR- Institute of Marine Research - Department of Zoology, Faculty of Sciences and Technology, University of Coimbra, 3004-517 Coimbra, Portugal.

${ }^{2}$ Department of Biological and Environmental Engineering, ICETA- University of Trás-os-Montes e Alto Douro, 5000 Vila Real, Portugal.

\begin{abstract}
Mosquitofish, Gambusia holbrooki, was introduced into the Iberian Peninsula in 1921, becoming widely distributed in freshwater systems associated to rural and urban areas. However, the impact of its introduction on natural aquatic communities in such areas has never been properly assessed. In this paper, we evaluate the influence of $G$. holbrooki on the zooplankton community of the river Mondego valley (Central Portugal). Spatial and temporal diet shifts were examined in two representative habitats of central Portugal, a typical rice field and a semi-natural protected wetland. Mosquitofish feed mainly on zooplankton (Copepoda, Cladocera, Rotifera and Ostracoda), although surface insects, such as aphids, collembolans, adult (imago) chironomids and other dipterans may constitute aditional food. Although Gambusia's ingestion rates are low, high population densities may cause a considerable predation pressure on zooplankton. Garnbusia was found to exert a stronger predation pressure on zooplankton in the rice field, where zooplankton presented scarcer populations, than in the semi-natural protected wetland. Consumption rates of Gambusia changed as a function of body size and reproductive period. Gambusia holbrooki exerted significant predation pressure on native zooplankton populations and certainly competed with other coexisting fish species.
\end{abstract}

Key words: Gambusia holbrooki, zooplankton, impact, predation pressure

\section{RESUMEN}

La gambusia, Gambusia holbrooki, fue introducida en la Peninsula Ibérica en 1921, estando ampliamente distribuida en las aguas continentales asociadas a areas rurales y urbanas. No obstante, el impacto de su introducción sobre las comunidades acuaticas naturales de dichas areas no ha sido adecuadamente determinada. En este trabajo, evaluamos la influencia de G. holbrooki sobre las comunidades del zooplancton del valle del rio Mondego (Centro de Portugal). Para ello se examinó la evolucidn espacial y temporal de la dieta en dos habitats representativos del centro de Portugal, un campo de arrozy una zona húmda seminatural protegida. Gambusia come principalmente zooplancton (Copepoda, Cladocera, Rotifera y Ostracoda), aunque insectos sufiperficiales como áfidos, colémbolos, adultos (imago) de quironómidos y otros dipteros pueden constituir un alimento adicional. Aunque las tasa de ingestidn de Gambusia son bajas, elevadas densidades poblacionales pueden producir una considerable presidn de depredacidn en el zooplancton. Se ha encontrado que Gambusia ejerce unafuerte presidn de depredacidn sobre el zooplancton en el campo de arroz, donde el zooplancton presenta poblaciones poco densas, que el la zona humeda seminatural protegida. Las tasas de consumo de Gambusia cambian en función de la tallay del periodo reproductivo. Gambusia holbrooki ejerce una presidn de depredacidn significativa sobre las poblaciones nativas del zooplancton y verdaderamente compiten con otras especies de peces con las que coexiste.

Palabras clave: Gambusia holbrooki, zooplancton, impacto, presidn de depredacidn

\section{INTRODUCTION}

Mosquitofish, Gambusia holbrooki (Girard) (Cyprinodontiformes: Poeciliidae) is native from the Eastern coast of the United States. It was introduced into temperate and tropical regions through mosquitoe control programmes (Cech \& Linden, 1986; Haynes \& Cashner, 1995; Homski et al., 1994; Lydeard \& Belk, 1993). In the Iberian Peninsula, mosquitofish were introduced 
in 1921 (Albuquerque, 1956). Today, it is commonly found in disturbed systems, close to both rural and urban areas. Mosquitofish is presently one of the most widely distributed freshwater fish species around the world, and is believed to be the most widely disseminated natural predator in the history of biological control (Bosford et al., 1987). Gambusia holbrooki has a high level of plasticity and survival capability, and will easily colonize new habitats. It will reproduce under most conditions, even when food is scarce. Mosquitofish is an opportunistic species. It feeds on zooplankton, aquatic and surface insects, snails, other fish species and algae (Cabral et al., 1998; Crivelli \& Boy, 1987; Garcia- Berthou, 1999; Hulbert \& Mulla, 1981; Colwell \& Schaefer, 1983; Daniels \& Felley, 1992; Offill \& Walton, 1999). The number of prey ingested by mosquitofish usually depends on its size relative to available prey. Diet changes seasonally with prey availability (Cabral et al., 1998).
Gambusia holbrooki is a voracious species, and has been considered a pest following its introduction into new habitats. Rupp (1996), for instance, reported Gambusia feeding on the eggs of economically-desirable fishes, preying on rare indigenous species and decreasing small native aquatic vertebrate and invertebrate populations. Gambusia has helped eradicate the mosquitoeborne malaria and its introduction is still advocated in some places (Hackett, 1937; in Rupp, 1996; Tabibzadel, 1970, Inei et al., 1992 in Legner, 1995; Singaravelu et al., 1997).

Trophic relationships between mosquitofish and zooplankton were investigated in two representative habitats of the river Mondego valley, a rice field and a semi-natural protected wetland. The aim of the present paper is to give estimates of the predation pressure on natural zooplankton populations, resulting from the introduction of Gambusia holbrooki in the Mondego river valley.

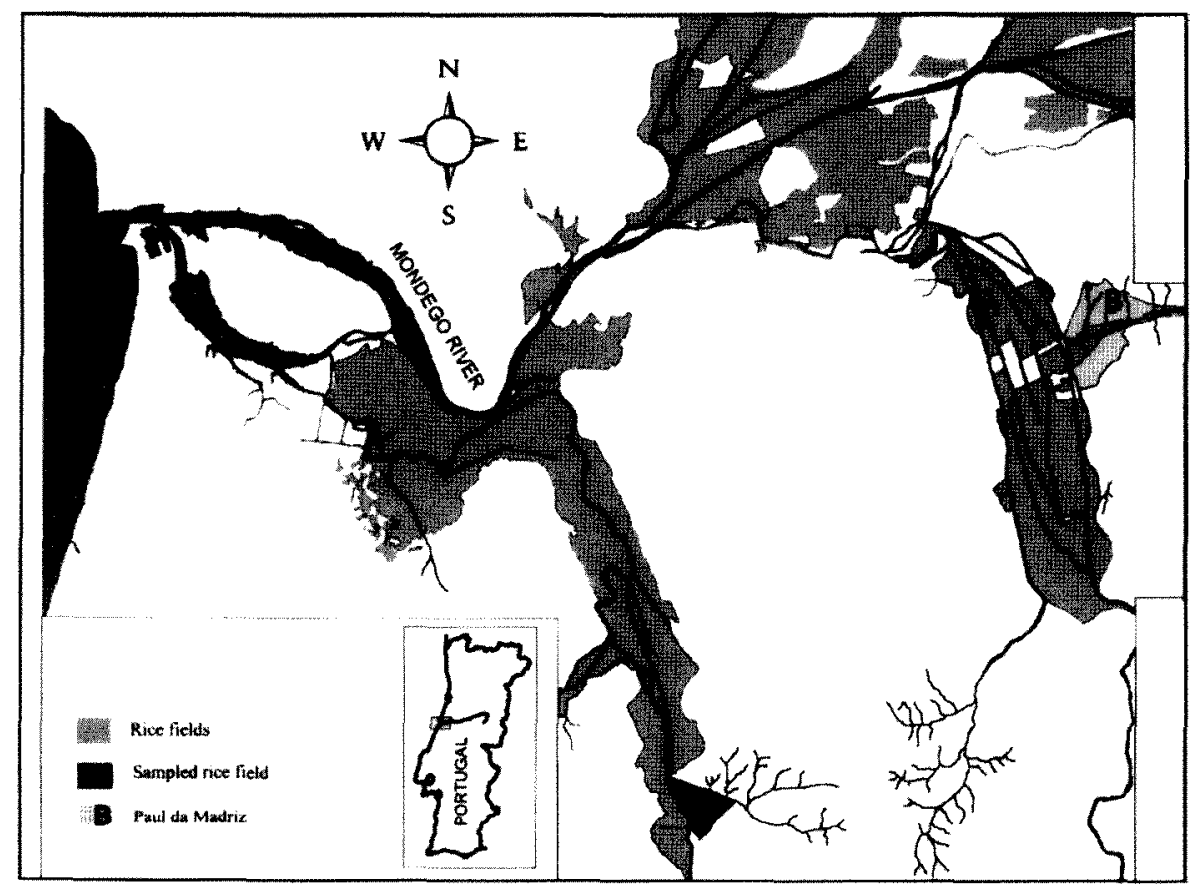

Figure 1. Location of sampling areas in the lower Mondego river valley. Situación de las areas de muestreo en el bajo valle del río Mondego. 
Table 1. Relative abundance (\%) of main prey in mosquitofish gut contents and calculated Ivlev electivity index values, in the rice field and in the semi-natural protected wetland in the lower Mondego river valley (Portugal). Abundancia relativa (\%) de las principales presas de gambusia en el contenido intestinal y valores del indice de preferencia de Ivlev en el arrozal y en la zona húmeda seminatural protegida en el tramo inferior del valle del rio Mondego (Portugal).

\begin{tabular}{|c|c|c|c|c|}
\hline \multirow[t]{2}{*}{ Preys } & \multicolumn{2}{|c|}{ Average of preys in the gut $(\%)$} & \multicolumn{2}{|c|}{ Ivlev Electivity Index } \\
\hline & Rice field & Semi-natural wetland & Rice field & Semi-natural wetland \\
\hline Copepoda & 59.I & 46.84 & 0.18 & -0.14 \\
\hline Cladocera & 19.45 & 16.56 & -0.2 & $\mathbf{0 . 0 3 7}$ \\
\hline Rotifera & 11.7 & 8.39 & -0.06 & 1 \\
\hline Ostracoda & 0.5 & 2.06 & 1 & -0.49 \\
\hline Collembola & 2.27 & 2.73 & -0.37 & -0.16 \\
\hline Aphidae & 4.65 & 7.45 & -0.32 & 1 \\
\hline Formicidae & 0.78 & 0.43 & -0.76 & -0.92 \\
\hline Hymenoptera & 0.07 & 0.41 & -0.92 & -0.67 \\
\hline Dytiscidae & 0.01 & 0.93 & -0.96 & -0.63 \\
\hline Chrysomelidae & 0 & 0.32 & 0 & -0.79 \\
\hline Hydraenidae & 0.08 & 0 & -0.71 & 0 \\
\hline Hydrophilidae & 0.06 & 0 & -0.95 & 0 \\
\hline Gastropoda & 0 & 0.03 & 0 & -0.86 \\
\hline Coleoptera $\mathrm{T}$ & 0.008 & 0 & -0.78 & 0 \\
\hline Chironomidae AD & 0.61 & 0.25 & & -0.84 \\
\hline Chironomidae LV & 0.3 & 0 & -0.85 & 0 \\
\hline Annelidae & 0 & 0.06 & 0 & -0.92 \\
\hline Diptera AD & 0.01 & 3.88 & -0.45 & 1 \\
\hline Arachnida & 0.01 & 0.36 & -0.91 & -0.19 \\
\hline Acariformes & 0 & 0.36 & 0 & -0.44 \\
\hline Notonectidae & 0 & 0.01 & 0 & -0.97 \\
\hline
\end{tabular}

T- terrestrial, AD- adult and LV- larvae

The numbers in bold are concerned to preferential Ivlev values

\section{MATERIALS AND METHODS}

\section{Study site}

The Mondego river valley is located in central Portugal $\left(40^{\circ} 10^{\prime} \mathrm{N}, 08^{\circ} 41^{\prime} \mathrm{W}\right)$ (Fig. 1). The valley is about 15,000 ha. The main agricultural crop is rice (Anastacio \& Marques, 1995). Winter is mild and summer hot and dry. Study sites were a typical of the area, rice field and a semi-natural protected wetland (Paul da Madriz), both located on the left margin of the river Mondego. Sampling took place in the main irrigation channel of the rice field, and in a heavily vegetated cannal in the wetland area.

\section{Field and laboratory procedures}

The sampling programe was carried out between April 1996 and May 1997. Samples were taken fortnightly during the main reproductive season (Cabral \& Marques, 1999), and monthly during the rest of the year.

Gambusia holbrooki was collected by electrofishing, at three sites chosen randomly. We used a semi-portable generator to supply a rectified DC current (350-600 V). Discharges lasted approximately 30 minutes, considered enough time to catch almost all fish in the sampling area (i.e. ranging between 3 and $16 \mathrm{~m}^{2}$ ). Sampling was from 10 to $13 \mathrm{~h}$, which is the most intense feed- 
ing period. Mosquitofish were immediately preserved in $4 \%$ neutralized formaldehyde. Within $48 \mathrm{hrs}$ of fixation, specimens collected were washed with water and preserved in $70 \%$ ethanol. Individuals were then counted and grouped according to eight size-classes, i.e. 1 (smaller than $10 \mathrm{~mm}$ in length); 2 (11-15 mm), 3 (16-20 $\mathrm{mm}), 4(21-25 \mathrm{~mm}), 5$ (26-30 mm), 6 (31-35 $\mathrm{mm}), 7(36-40 \mathrm{~mm})$ and 8 (larger than $41 \mathrm{~mm}$ in length). Gut contents were examined in five specimens of each size-class sampled at each site. In size-classes 3, 4, and 5, some females and males exhibited identical size and five individuals of each sex were then examined. For gut content analysis, an excision was made from the esophaegus up to the ventral region and preys and/or vestiges identified and counted.
Zooplankton samples were obtained by horizontal trawls of a $200 \mathrm{~mm}$ mesh plankton net. A digital flow meter was used to determine the volume of water passing through the net. Samples were immediately preserved in $4 \%$ neutralized formaldehyde and organisms sorted by size and identified in the laboratory. Many rotifers, nauplii, copepodites of initial stages and cladoceran juveniles were smaller than $200 \mathrm{~mm}$, thus passing through the mesh size used. Therefore, only gross seasonal trends in zooplankton distribution were examined.

Surface and terrestrial insects were also collected, as described in Cabral et al. (1998), in order to estimate if Gambusia may change its diet preferences as a function of the availability of these prey.
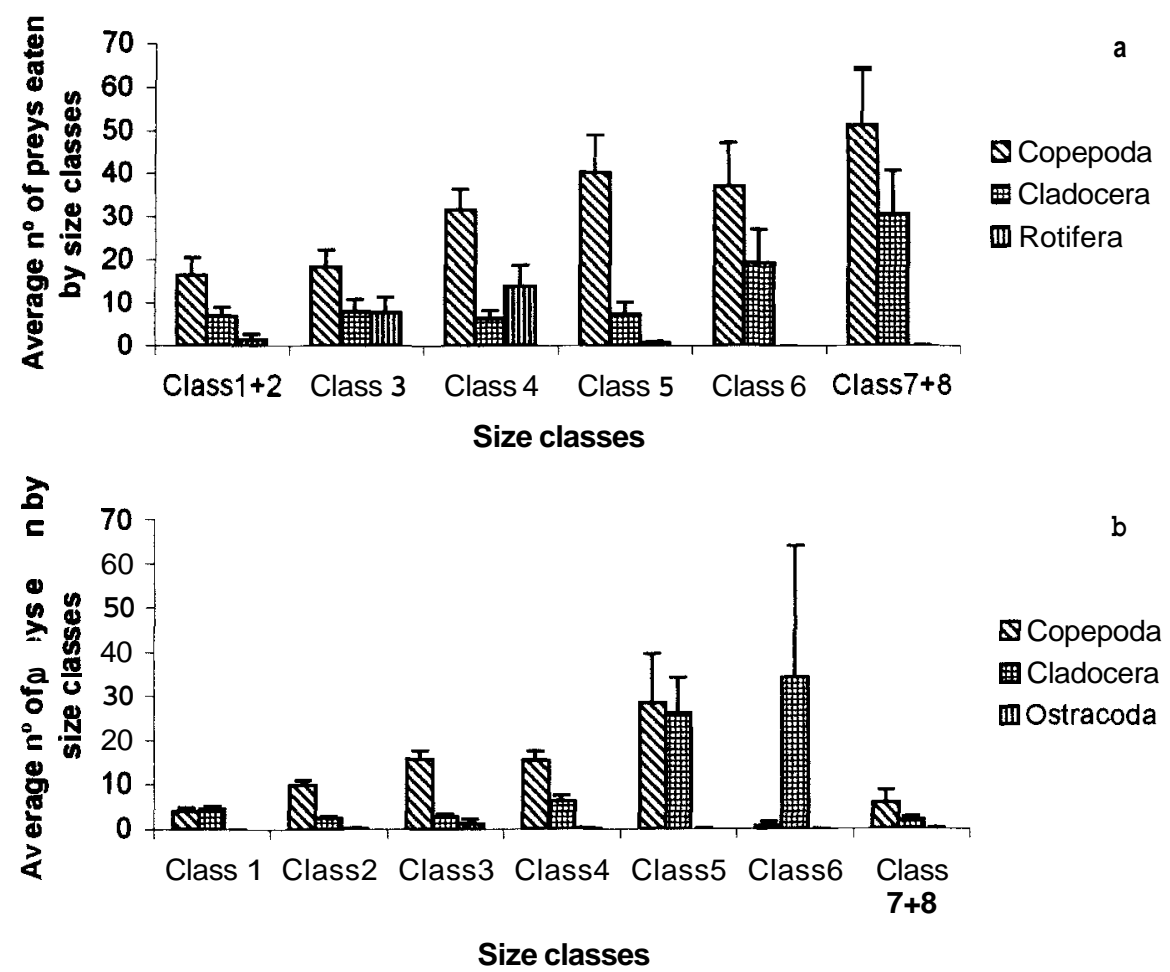

Figure 2. Mean number of prey items (Copepoda, Cladocera and Rotifera) eaten by mosquitofish of each size class (i.e. I: smaller than 10 $\mathrm{mm}$ in length; 2: 11-15 mm, 3: 16-20 mm, 4:21-25 mm, 5: 26-30 mm, 6: 31-35 mm, 7: 36-40 mm, and 8: larger than $41 \mathrm{~mm}$ in length) between April 1996 and May 1997. Bars are of one standard error at either side of the mean. Habitats were, a- rice field, b- semi-natural wetland. Número medio de presus (Copepodu, Cludoceruy Rotifera) comidas por gambusia de cudu clase de tamaño (así, I: menores de I0 mm de longitud; 2: $11.15 \mathrm{~mm}, 3: 16-20 \mathrm{~mm}, 4: 21-25 \mathrm{~mm}, 5: 26-30 \mathrm{~mm}, 6: 31-35 \mathrm{~mm}, 7: 36-40 \mathrm{~mm}$, y $8:$ mayores de $41 \mathrm{~mm}$ en longitud) entre Abril de 1996y Mayo de 1997. Las barras indicun el error estándar a cada ludo de la media. Los habitats fueron, a-cumpo de arroz, b-zona húmeda seminatural. 


\section{Data analyses}

Prey preferences were evaluated using Ivlev's "Electivity Index" (Ivlev, 1961), defined as $E_{i}=\left(r_{i}-P_{i}\right) /\left(r_{i}+P_{i}\right)$, where $r_{i}$ is the relative abundance of a prey in a predator's diet and $P_{i}$ is the prey's relative abundance in the ecosystem. $E_{i}$ is scaled so that $\mathrm{E},=-1$ corresponds to total avoidance of prey $\mathrm{i}, \mathrm{E},=0$ represents non-selective feeding, and $E_{i}=+1$ shows exclusive feeding on a given prey $\mathrm{i}$. The value -0.5 was the lower limit identifying "preferential" prey. To investigate possible differences in the number of prey ingested by different size-classes and sexual groups (i.e. immatures, males, non-gravid and gravid females, NGF and GF, respectively), a Kruskal-
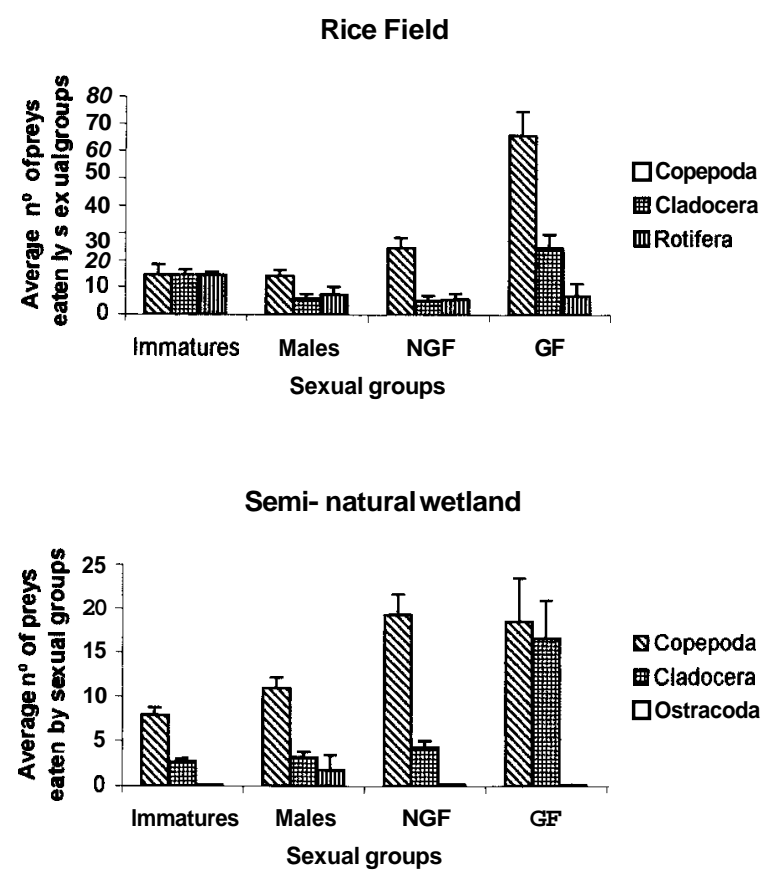

Figure 3. Mean number of prey items eaten by sexual groups of mosquitofish (i.e. immatures, males, non-gravid females: NGF, and gravid females: GF) collected between April 1996 and May 1997 from a- a rice field and, b- a semi-natural wetland. Bars are of one standard error at either side of the mean. Numero medio de presas comidas por grupos sexuales de gambusia (inmaduros, muchos. hembrus no grávidas: NGF, y hembrus grávidas: GF) capturudos entre Abril de 1996 y Mayo de 1997 de a-el campo de arroz y, b-la zona húmeda seminatural. Las barras indicun una unidad del error estandur a cada ludo de la media
Wallis rank analysis was used, followed by a nonparametric multiple comparisons test (Zar, 1996). To test whether the diet of Gambusia was dependent on seasonal changes in prey availability, the proportion of dominant prey species in stomach contents and habitat were compared. The potential predation pressure caused by mosquitofish on zooplankton was estimated from prey consumption estimates. To do this, we estimated mosquitofish densities (ind $\mathrm{m}^{-2}$ ) each month, based on the whole set of samples. Densities were then multiplied by the corresponding monthly mean number of prey ingested. To test whether predation pressure (number of prey caught by $\mathrm{m}^{2}$, ind $\mathrm{m}^{-2}$ ) was independent or not from the zooplankton, expressed as a proportion of total prey available in both studied habitats, Pearson correlation analysis were performed on both variables (i.e. mosquitofish density and zooplankton-prey proportion of total prey). Also, correlation analysis validated calculations of predation pressure from prey areal densities.

\section{RESULTS}

The most frequent zooplankton groups were Copepoda and Cladocera. According to Ivlev's Electivity Index, the preferential zooplankton prey of mosquitofish in the rice field were copepods, cladocerans and rotifers, while in the seminatural wetland, preferred prey were copepods, cladocerans and ostracods (Table 1).

Results from the Kruskal-Wallis one-way analysis of variance by ranks, showed that, for the rice field, only cladocerans and rotifers were ingested in significantly different quantities by different mosquitofish size classes (copepoda $\chi^{2}=9.27$, n.s.; cladocera $\chi^{2}=15.76, p<0.01$ and rotifera $\chi^{2}=15.36, p<0.01$.) (Fig.2a). Males and females ingested copepods and cladocerans in significantly different amounts (copepoda $\chi^{2}=39.56, \mathrm{p}<0.001$; cladocera $\chi^{2}=41.10, \mathrm{p}<0.001$ and rotifera $\chi^{2}=6.52$, n.s.) (Fig. 3a). In the seminatural wetland, mosquitofish size-classes and sexual groups ingested significantly different amounts of both copepods and cladocerans (size 
Cladocera

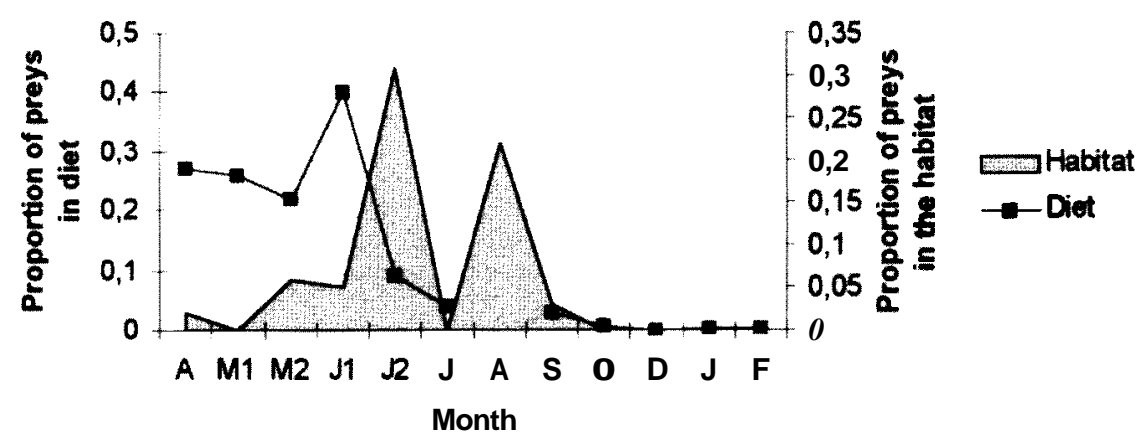

Copepoda

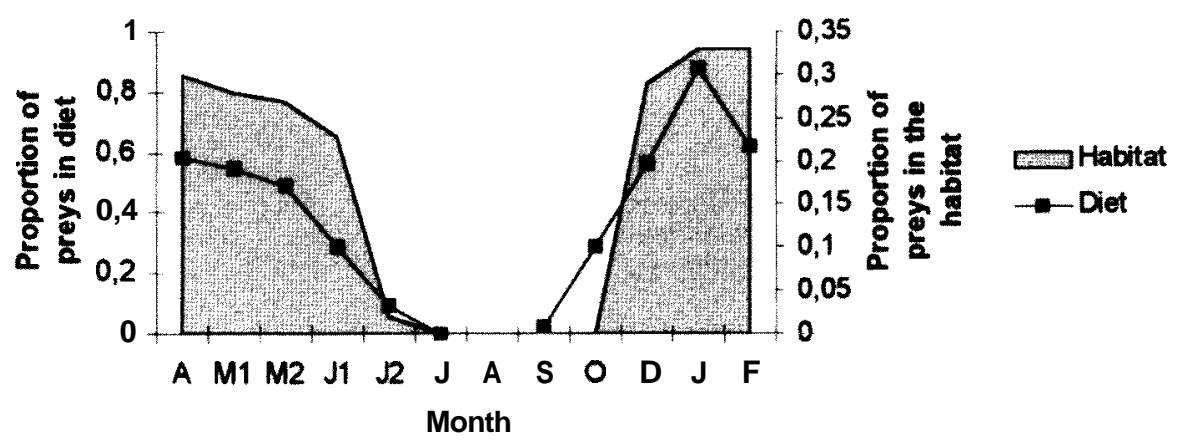

Rotffera

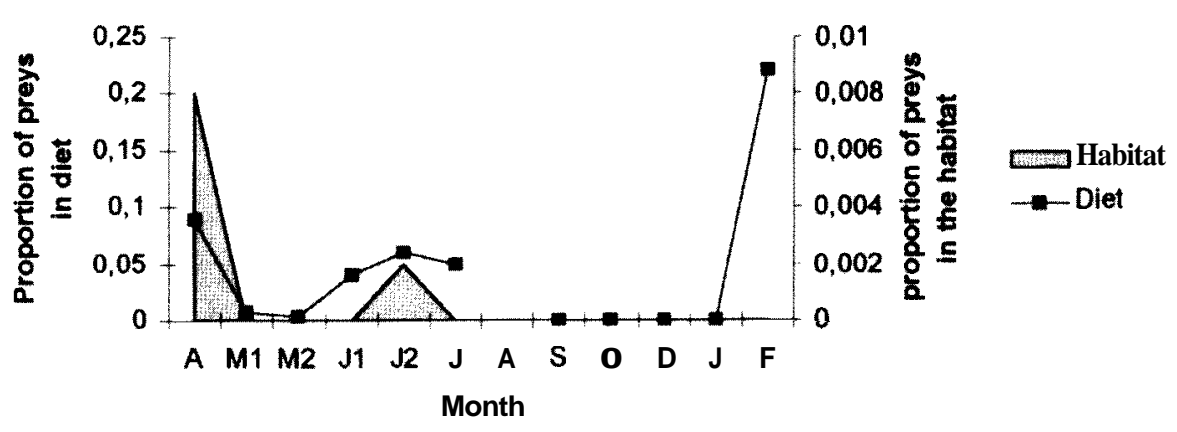

Figure 4. Proportion of mosquitofish main prey (i.e. Cladocera, Copepoda and Rotifera) found in their stomach contents and in the habitat, during the sampling period (April 1996-May 1997) in the rice field. A-Cladocera, B-Copepoda and C- Rotifera. Proporcidnde las principales presas de gambusia (Cludoceru, Copepoduy Rotifera) halladas en el contenido estomacaly el el hábitat durante elperiodo de muestreo (Abril de 1996 a Mayo de 1997) en el campo de arroz. A- Cludoceru, B- Copepodu y C-Rotifera). 
classes: copepoda $\chi^{2}=24.78, \mathrm{p}<0.001$; cladocera $\chi^{2}=24.12, \mathrm{p}<0.001$ and ostracoda $\chi 8, \mathrm{p}<0.001$; cladocera $\chi^{2}=7.68$, n.s. and ostracoda $\chi^{2}=2.27$, n.s.) (Figs. 2b and 3b, respectively). Multiple comparison tests showed that, in the rice field, the largest size-classes (class $7+8$ ) clearly ingested more cladocerans, while medium-small fish apparently preferred rotifers (Fig. 2a). Gravid females ingested more copepods and cladocerans than the other groups (Fig. 3a). In the semi-natural wetland, size-classes 5 and 6 ingested more zooplankton than the other size-classes (Fig. 2b). Gravid females apparently preyed upon cladocerans more than the other sexual groups did (Fig. $3 b)$. On the other hand, non-gravid females ingested more copepods than gravid females, and both female groups ingested more copepods than males and immature fish (Fig. 3b).

Estimates of the proportion of different zooplankton prey in stomaches and in the habitat allowed to examine mosquitofish diet seasonal changes. In the rice field, copepods were more abundant from October to the beginning of June, while cladocerans were common in May and June, disappeared in July, increased again in August and then declined gradually to their total disappearance in October. The mesh size of sampling nets was too large and, thus, rotifers were not adequately collected. Proportional values plotted are therefore indicative of real densities but must be regarded with caution. The analysis of these samples indicated a higher proportion of rotifers in April and mid-June. Large numbers during winter were of periphytic species (Fig. 4). Terrestrial prey (e.g. Collembola, aphids, adult chironomids and other adult Diptera) were more fi-equent fi-om June to September, coinciding with the period when there were proportionally less zooplankton, both in the habitat and in guts analysed (Fig. 5). In the wetland, copepods and cladocerans were frequent throughout the year, except cladocerans in July. Ostracods were relatively abundant in May and September. Copepods were more important in mosquitofish diet than cladocerans and ostracods between April and July. From July, the proportion of copepods in their diet decreased and cladocerans and ostracods became main prey (Fig. 6). The proportion of terrestrial prey (i.e. Collembola, arachnids and acarids) in the habitat was larger fi-om September to December than the rest of the year. In gut contents, terrestrial prey were more abundant in April, October and March (Fig. 7). These data suggest Gambusia ingests prey depending on availability in the environment. This trend was particularly clear in the rice field.

During summer, following a decrease in zooplankton, mosquitofish switched prey categories. In the rice field, terrestrial prey were available

\section{Terrestrial preys}

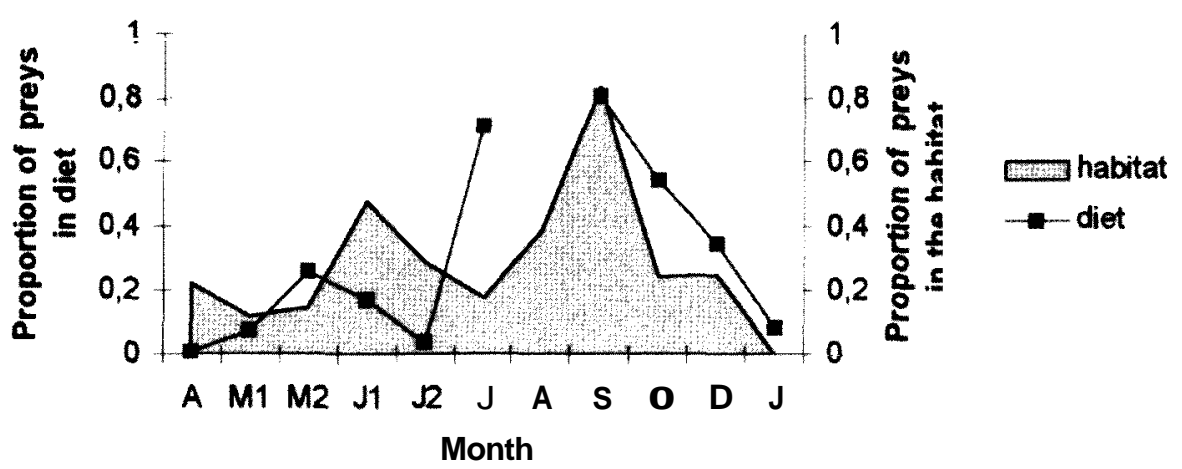

Figure 5. Proportion of mosquitofish main terrestrial prey found in stomache contents and in the habitat, during the sampling period (i.e. April 1996-May 1997) in the rice field. Samples in May and July were taken fortnightly (M1, M2 and J1, J2). Proporción de las principales presas de gambusias de origen terrestre halladas en el contenido intestinal y en el habitat durante el periodo de muestreo (Abril de 1996 - Mayo 1997) en el campo de arroz. Las muestras de de Mayo y Julio se tomaron quincenalmente /M1, M2 y J1, J2). 


\section{Cladocera}

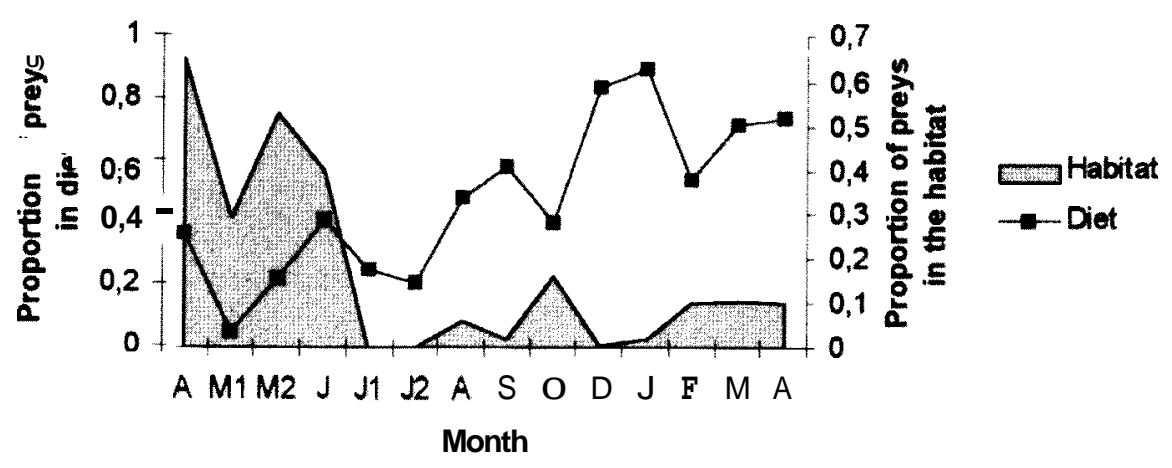

Copepoda

B

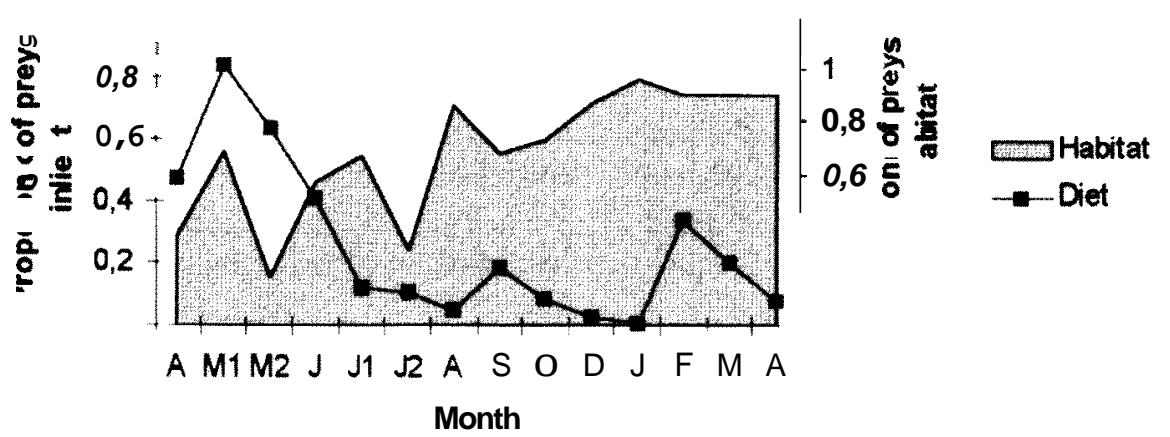

Ostracoda

C

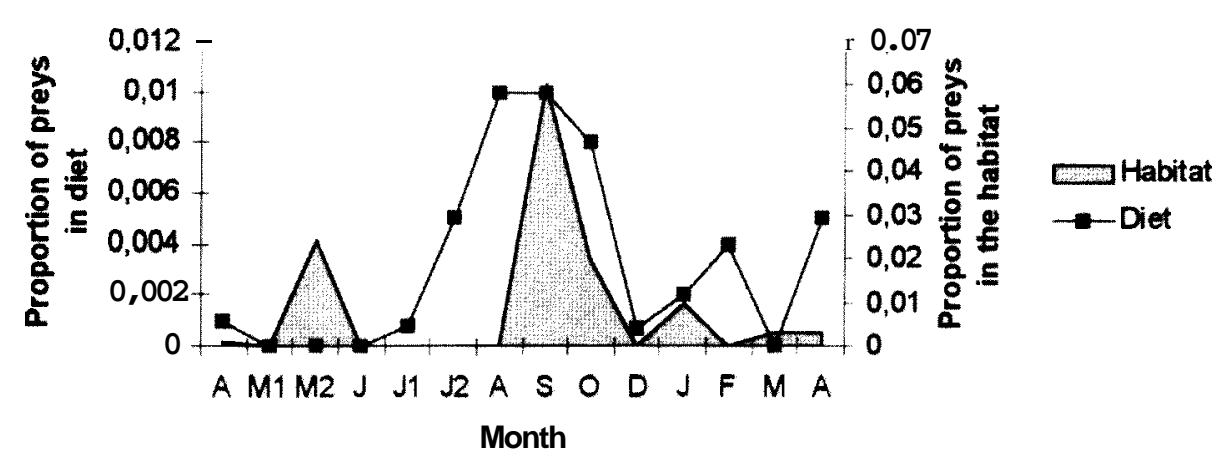

Figure 6. Proportion of mosquitofish main prey (i.e. Cladocera, Copepoda and Rotifera) found in the stomach contents of mosquitofish and in their habitat, during the sampling period (April 1996-May 1997) in the semi-natural wetland. The proportions of these prey in the habitat, refer to mainly adult crustaceans. A-Cladocera, B-Copepoda and C-Ostracoda. Samples in May and July were taken fortnightly (M1, M2 and J1, J2). Proporción de las principales presas de gambusia (Cladocera, Copepoday Rotifera) halladas en el contenido estomacaly en su habitat durante elperiodo de muestreo (Abril 1996 - Mayo 1997) en la zona húmeda seminatural. Las proporciones de estas presas en el habitat se refieren principalmente a crustaceos adultos. A-Cladocera, B-Copepodu y C-Ostracodu. Las muestras de Mayo y Julio se tomaron quincenalmente (M1, M2 y J1,J2). 


\section{Terrestrial preys}

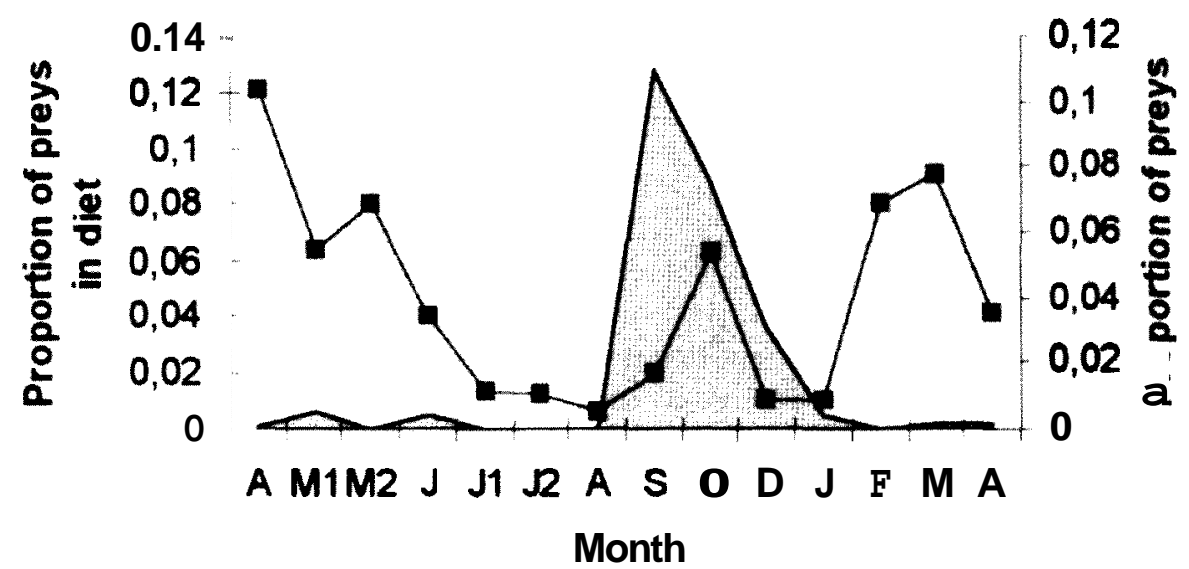

Figure 7. Proportion of mosquitofish terrestrial prey found in stomach contents of mosquitofish and in the habitat, during the sampling period (April 1996-May 1997) in the semi-natural wetland. Samples in May and July were taken fortnightly (M1, M2 and J1, J2). Proporcidn de presas terrestres de gambusia halladas en su contenido estomacaly en el habitat durante elperiodo de estudio (Abril 1996- Mayo1997) en la zona húmeda seminatural. Las muestras de Mayo y Julio se tomaron quincenalmente (M1, M2 y J1, J2).

throughout the year. However, these prey were more abundant in stomach contents from July to October. In the wetland, terrestrial prey were proportionately less frequent in the diet of mosquitofish. A certain "preference" for terrestrial prey was detected in April and October, coinciding with small peaks in abundance (Figs. 5 and 7). Chironomids and dipterans were ingested more frequently by gravid females than by other groups. In the wetland, arachnids (i.e. spiders and acarids) were alternative prey to zooplankton, and were ingested by all size classes.

Highest predation pressure occurred at peak fish densities, although each individual fish ingested a lower number of prey. Predation on cladocerans was higher in May and in June in the rice field, when fish densities were moderate and individual consumption higher. In August, high predation pressure on cladocerans occurred at high fish density and low individual consumption rates. On copepods, predation pressure was higher in June, at high individual consumption rates. Rotifers were more predated upon in August, when fish densities were high and individual consumption rates lower (Fig. 8).
In the semi-natural wetland, predation pressure on cladocerans was high in July, with large fish densities. Predation pressure on copepods in the wetland was high in August, when individual fish consumption rates were low and fish densities high. On ostracods, On ostracods, predation pressure was high in August, when they were scarce anyway, and fish density and individual fish consumption rates were higher (Fig. 9).

The Pearson correlation analysis showed that predation pressure on copepods in the rice field $(\mathrm{r}$ $=0.36$, n.s.) and in the semi-natural wetland ( $\mathrm{r}=$ -0.55, n.s.) was independent of availability of this prey to mosquitofish in both habitats. The same result was obtained for rotifers $(r=0.17$, n.s. $)$ and ostracods ( $\mathrm{r}=0.52$, n.s.). Mosquitofish predation pressure on cladocerans in the rice field was not significant either ( $r=-0.05$, n.s.). In the semi-natural wetland, however, predation pressure on cladocerans was higher when this prey type was scarce $(r=-0.67, p<0.01)$. High mosquitofish predation on zooplankton (i.e. ind $\mathrm{m}^{-2}$ ) does not always result from high availability. This suggests gut content analysis gives good estimates of predation pressure on prey. 


\section{Cladocera}

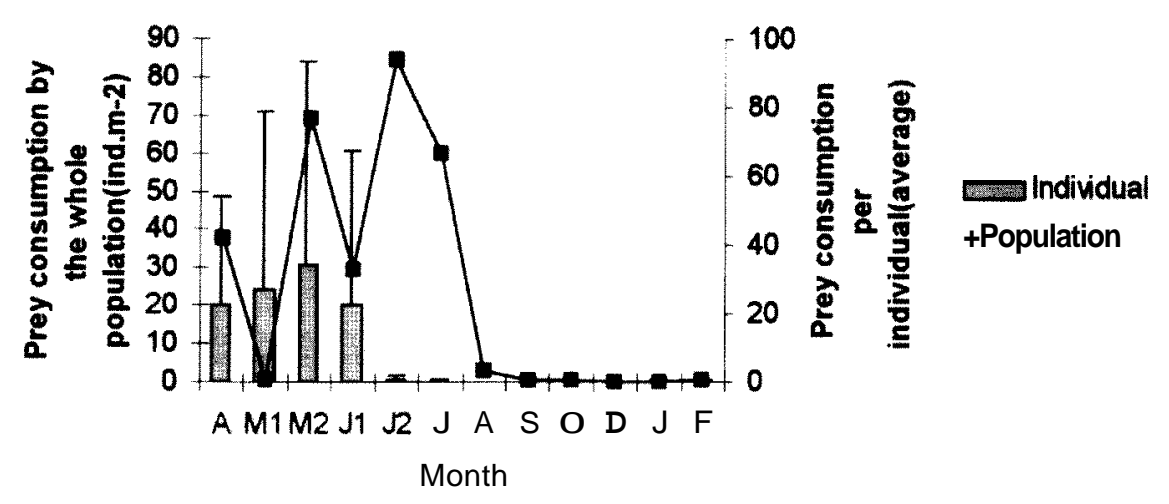

\section{Copepoda}

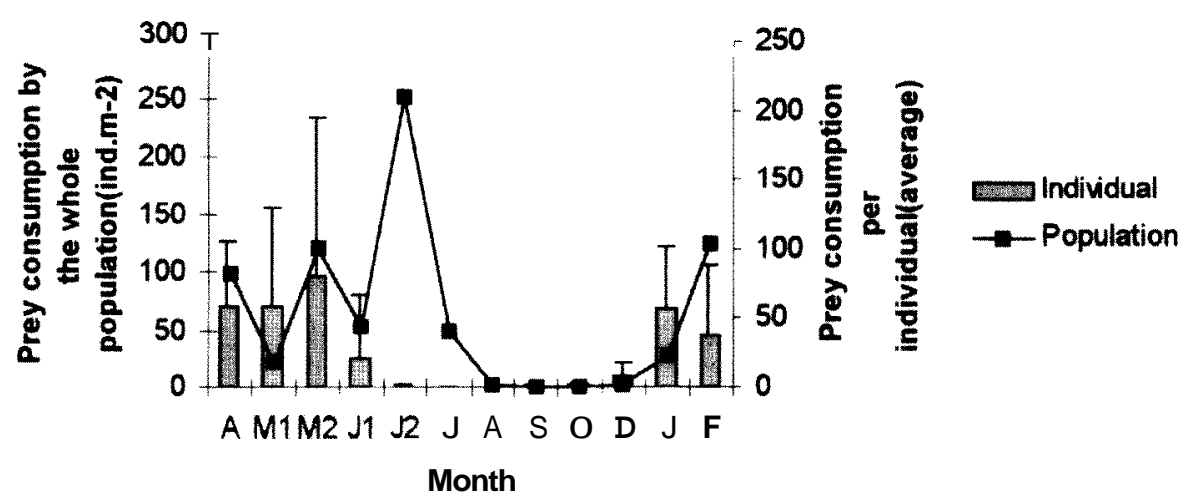

Rotifera

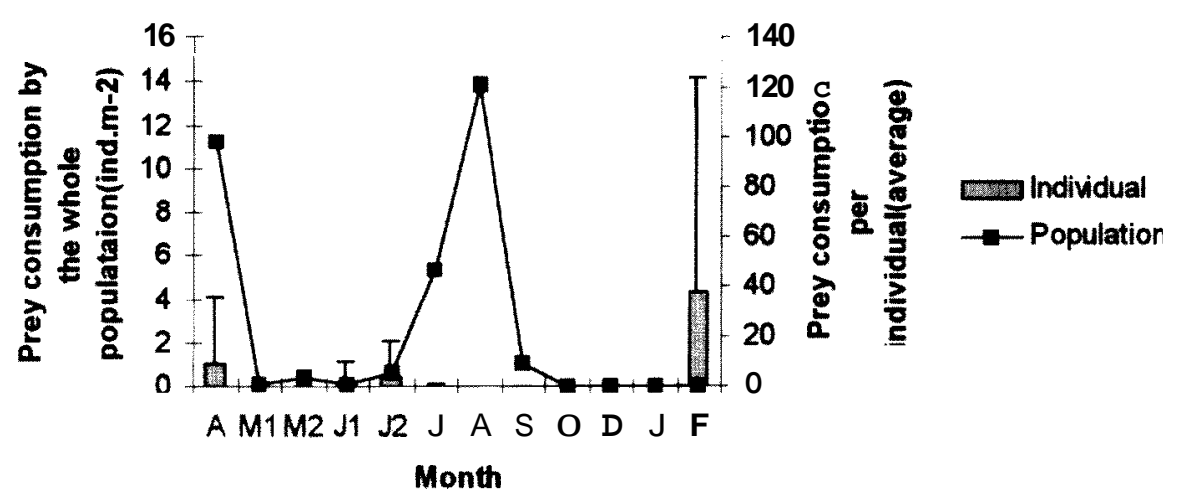

Figure 8. Prey consumption (ind m-2) by the whole mosquitofish population in the rice field. A- Cladocera, B-Copepoda and C- Rotifera. Samples in May and July were taken fortnightly (M1, M2 and J1, J2). Consurno de presas (ind m-2) para toda la población de garnbusias en arrozal. A-Cladocera. B-Copepoday C-Rotifera Las muestras de Mayo y Julio se tomaron quincenalmente (M1, M2 y J1, J2). 


\section{Cladocera}

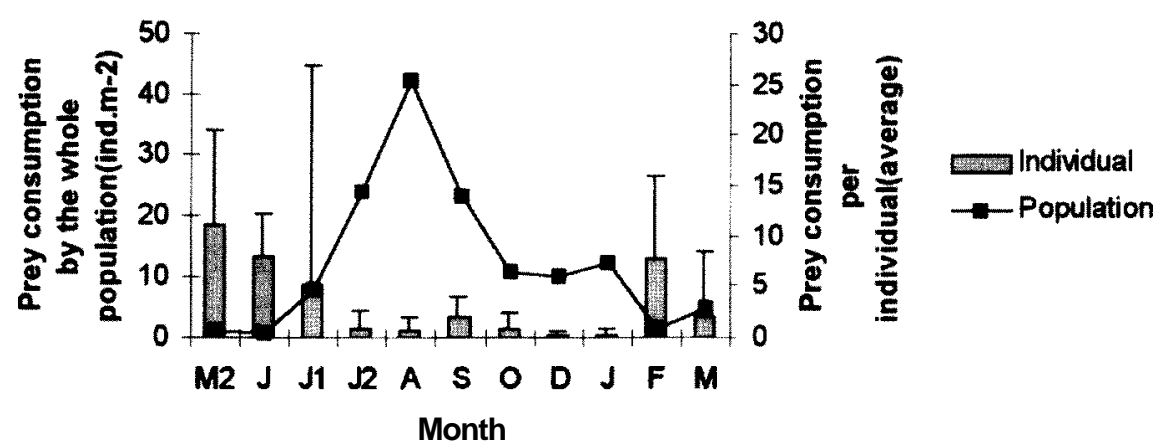

\section{Copepoda}

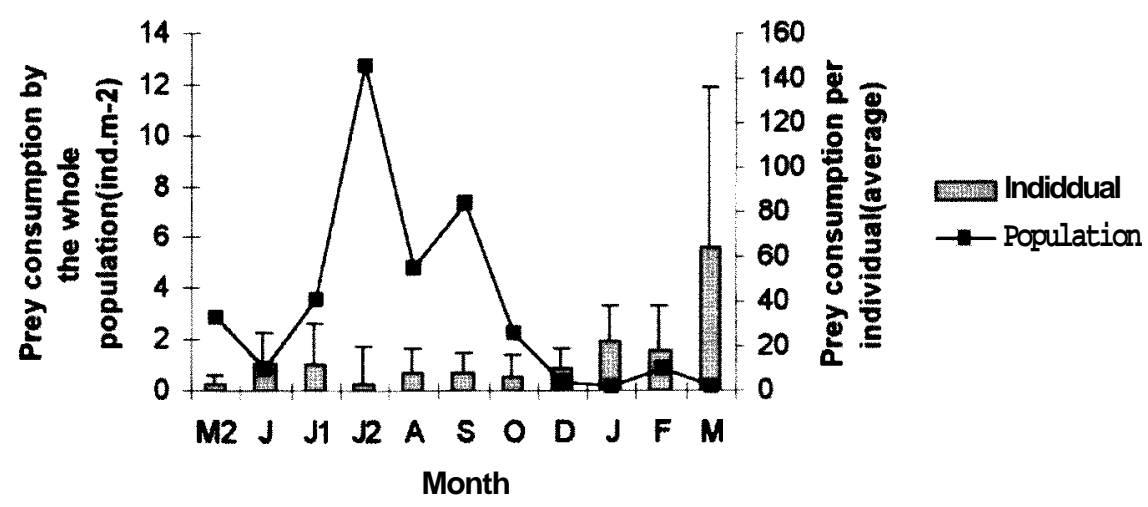

\section{Ostracoda}

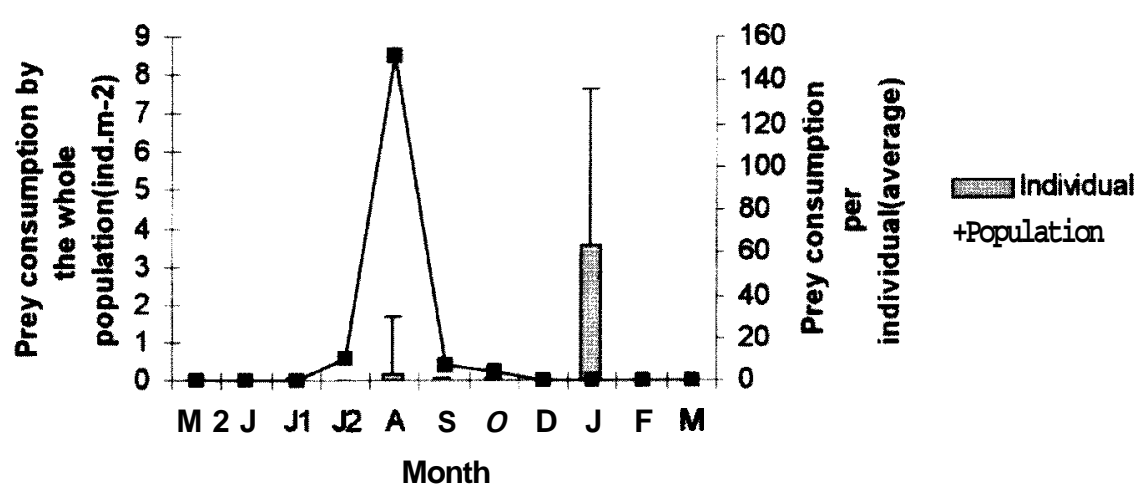

Figure 9. Prey consumption (ind $\mathrm{m}-2$ ) by the whole mosquitofish population on prey in the semi-natural wetland. A- Cladocera, B-Copepoda and C- Ostracoda. Samples in May and July were taken fortnightly (MI, M2 and J1, J2). Consumo de presas (ind m-2) para toda lapohlacion de gambusias en la zona húmeda seminatiral A-Cladocera, B-Copepoday C-Ostracoda. Lus muestras de Mayo y Julio se tomaron quincenalmente (M1, M2 y JI, J2). 


\section{DISCUSSION}

Mosquitofish are morphologically adapted to feed near the water surface, having a flattened head and a terminal upward-directed mouth. Also, the position of the head during feeding is flexible, so the mouth can change from a dorsoterminal to a ventral position. This flexibility allows mosquitofish to feed at the surface, on the benthos and in the water column (Arthington \& Marshall, 1999). The analysis of stomach contents revealed, in agreement with other studies (Colwell \& Shaefer, 1983; Crivelli \& Boy, 1987; Daniels \& Felley, 1992; Hulbert \& Mulla, 1981; Mansfield \& Mcardle, 1998; Cabral et al., 1998), that mosquitofish fed primarily near the surface on copepods and cladocerans, both in the rice field and in the semi-natural wetland. Hulbert \& Mulla (1981) concluded that cladocerans were more vulnerable to mosquitofish predation than copepods. In our study area, however, we observed the opposite, copepods being the most ingested prey group $(59.1 \%$ in the rice field and $46.8 \%$ in the wetland). However, gut content ratios (Cladocera vs. Copepoda) could be explained by respective availability, as copepods were generally much more abundant than cladocerans (rice field: $62.8 \%$ the copepods vs. $16.1 \%$ the cladocerans; wetland: $61.7 \%$ the copepods vs. $16.7 \%$ the cladocerans; Cabral et al., 1998). Fish pigmentation, feeding behaviour and body shape can also influence predators' choice (O'Keefe et al., 1998; Atsuhi \& Hiroaki, 1998; Viitasalo et al.1998).

Garman (1991) explained the ingestion of terrestrial prey by a cyprinid species as a general response of predator fish to seasonal decreases in availability of aquatic prey. In our study, although terrestrial prey were present all year, their consumption increased during summer, suggesting the switch to terrestrial prey was a response to zooplankton scarcity (Figs.4, 5, 6 and 7).

The increase in mosquitofish predation (i.e. ind ingested $\mathrm{m}^{-2}$ ) was independent of prey availability, representing a real measure of trophic pressure. Before the reproduction period of mosquitofish, calculated predation pressure was not intense because prey were abundant, but fish densities low. During spring and the beginning of summer (i.e. the reproduction period), mosquitofish density increased and intense feeding on zooplankton was registered. Densities of immature fish were high during this period and they are known to feed almost exclusively on zooplankton. Wurstsbaugh et al. (1980) explained that the immature mosquitofish could cause a higher impact on prey populations than adult fish, because they are able to consume over $100 \%$ of their own weight daily. As immature individuals grow in size, they are able to feed on a wider range of zooplankton. Large-bodied zooplankton will replace smaller species under intense predation regimes (Brooks \& Dodson 1965; Wetzel, 1993). Intense predation pressure was exerted at high fish density, although, occasionally, predation pressure was due to large individual consumption.

Zooplankton populations often decline by mid-summer. Strong predation by mosquitofish can enhance this decline and cause a more durable "perturbation" on zooplankton. Actual lower Mondego river valley zooplankton will decrease and small zooplankton will replace them.

Like other Gambusia species, the ability of Gambusia holbrooki to adapt to different, often harsh, habitats by modifying its life history (Haynes \& Cashner, 1995), may explain differences between the two populations studied in the lower river Mondego valley. In the present study, we examined predation pressure of Gambusia holbrooki on its main prey, zooplankton. Mosquitofish might have strong effects on copepod and cladoceran populations. Direct and indirect impacts of mosquitofish on vulnerable indigenous fish species could be important. This is an issue in bad need of further research.

The introduction and establishment of exotic species is apparently more difficult in undisturbed, natural or semi-natural ecosystems. Habitat protection is thus needed, particularly when fish species are deliberately displaced and, for instance, aquarium fishes introduced into natural freshwater systems. 


\section{ACKNOWLEDGEMENTS}

This study is part of a Master thesis of the first author and was supported by a FCT (Portuguese National Board of Scientific Research) grant (PRAXIS XXI/BM/19393/99).

\section{REFERENCES}

ALBUQUERQUE R. M. 1956. Peixes de Portugal e Ilhas adjacentes. Chaves para a sua determinação. Portugalia Acta Biologica, 5B, 1164 p.

ANASTÁCIO P. M. \& J. C. MARQUES. 1995. Population biology and production of the Red Swamp crayfish Procambarus clarkii (Girard) in the lower Mondego River Valley, Portugal. $J$. Crustacean Biol., 15: 156-168.

ARTHINGTON A H. \& C. J. MARSHALL. 1999. Diet of the Exotic Mosquitofish, Gambusia holbrooki, in an Australian Lake and Potential for Competition with Indigenous fish Species. Asian Fisheries Science, 12(199): 1-16.

BOSFORD L. W., B. VONDRACEK, T. C. WAINWRIGHT, AL. LINDEN, R. G. KOPE, D. E. REED, JJ. \& J. CECH. 1987. Population development of the mosquitofish, Gambusia affinis, in rice fields. Environ. Biol. Fish., 20: 143-154.

BROOKS, J.L. \& S.I. DODSON, (1965), Predation, body size, and composition of plankton, Science, 150:28-35.

CABRAL J. A., C. L. MIEIRO \& J. C. MARQUES. 1998. Environmemtal and biological factors influence the relantionship between a predator fish, Gambusia holbrooki, and its main prey in rice fields of the Lower Mondego River Valley (Portugal). Hydrobiologia, 382: 4 1-51.

CABRAL J. A. \& J. C. MARQUES. 1999. Life history, population dynamics and production of eastern mosquitofish, Gambusia holbrooki (Pisces, Poeciliidae), in rice fields of the lower Mondego River Valley, western Portugal. Acta Oecologica, 20(6): 607-620.

CECH J.J.J. \& A. L. LINDEN. 1986. Comparative Larvivourous effects of Mosquitofish and Sacramento Blackfish in Experimental Rice Fields. Proceedings and Papers of the Fifty-Third Annual Conference of the California Mosquito And Vector Control Association, Inc.,January 27 thru January 30, 1985, Published February 14.
COLWELL A. E. \& C. H. SCHAEFER. 1983. Effects of an Insect Growth regulator on Plankton and Gambusia affinis .Aquatic Toxicology, 4: 247-269.

CRIVELLI A. J. \& V. BOY. 1987. The Diet of Mosquitofish Gambusia affinis (Baird \& Girard) (Poeciliidae) in the Mediterranean France. Ver. Ecol. (Terre Vie), Vol. 42.

DANIELS G. L, \& J. D. FELLEY. 1992. Life History and Foods of Gambusia affinis in Two Waterways of Southwestern Louisiana. The Southwestern Naturalist, 37(2): 157-165.

GARCIA- BERTHOU E. 1999. Food of introduced mosquitofish: ontogenetic diet shift and prey selection. Journal of Fish Biology, 55: 135-147.

GARMAN G. C. 1991. Use of terrestrial arthropod prey by a stream-dwelling cyprinid fish. Environmental Biology of Fishes, 30: 325-331.

HAYNES J. L. REED J.J. \& C. CASHNER. 1995. Life history and population dynamics of the western mosquitofish: a comparision of natural and introduced populations. Journal of Fish Biology, 46: 1026-1041.

HOMSKI D., M. GOREN \& A. GASITH. 1994. Comparative evaluation of the larvivorous fish Gambusia affinis and Aphanius dispar as mosquito control agents. Hydrobiologia, 284: 137-146.

HULBERT S. H. M. \& S. MULLA. 1981. Impacts of mosquitofish (Gambusia affinis) predation on plankton communities. Hydrobiologia, 83: 25-151.

IVLEV V. S. 1961. Experimental ecology of the feeding of fishes. New Haven: Yale Univ. press. 302 pp.

LEGNER E. F. 1995. Biological control of Diptera of medical and veterinary importance. J. Vector Ecol., 20:59-120.

LYDEARD C. \& M. C. BELK.1993. Management of indigenous fish species impacted by introduced mosquitofish: an experimental approach. Southwest. Nat., 38: 370-373.

MANSFIELD S. \& B. H. MCARDLE. 1998. Dietary composition of Gambusia affinis (Family Poecilliidae) populations in the northen Waikato region of New Zealand. New Zealand Journal of Marine and Freshwater Research, 32: 375-383.

OFFILL Y. A, \& W. WALTON. 1999. Comparative Efficacy of the Threespine Stickleback (Gasterosteus aculeatus) and the Mosquitofish (Gambusia affinis) for Mosquito Control. Journal of the American Mosquito ControlAssociation, 15(3): 380-390.

RUPP H. R. 1996. Adverse Assessments of Gambusia affinis: an Alternate View for Mosquito Control Practitioners. Journal of the American Mosquito Control Association, 12(2): 155-166. 
SINGARAVELU G., S. MAHALINGAM, K. J. BHARATHI. 1997. Predatory efficiency of larvivorous fish Gambusia affinis on the mosquito larvae of Aedes aegypti and Anopheles stephensi. Current Science, Vol.72, $\mathrm{N}^{\circ} 7$.

WETZEL R. G. 1993. Limnology, $2^{\text {nd }}$ Ed. Fundação Calouste Gulbenkian, Lisboa.
WURSTBAUGH W., J. J., J. CECH \& J. COMPTON 1980. Effect of fish size on prey selection in Gambusia affinis. Proceedings and Papers of the Forty- Eighth Annual Conference of the California Mosquito and Vector Control Association. Inc. January 20-23.

ZAR J. H.. 1996. Biostatistical Analysis. Third Edition, Prentice hall International editions, 662 pp. 